\title{
UDC 378.011.3-051:159
}

\section{THE PROBLEM OF TRAINING A HIGH SCHOOL TEACHER IN MODERN SCIENTIFIC AND PEDAGOGICAL THEORY ПРОБЛЕМА ПІДГОТОВКИ ВИКЛАДАЧА ЗАКЛАДУ ВИЩОЇ ОСВІТИ У СУЧАСНІЙ НАУКОВО-ПЕДАГОГІЧНІЙ ТЕОРІї}

Cherepiekhina O.A./ Черепехина O.A.

k.p.s., doc. / к.n.н., доų. ORCID: 0000-0001-6970-1217

Oles Honchar Dnipro National University, Dnipro, Dvoryanska, Gagarina avenue, 72, 49000 Днепровский национальный университет им. О. Гончара, Днепр, просп. Гагарина, 72, 49000

\begin{abstract}
The article presents the results of scientific and theoretical research of the author in the field of training of high school teachers in modern pedagogical theory. The author stated that the problem of training of high school teachers has been the subject of specialized scientific research in pedagogical theory for decades. In high school educators have formed some traditions for studying various aspects of the vocational training of future high school teachers, as well as trends emerged in looking at the current state of higher education. In the context of our study it will be useful to highlight scientific advances in pedagogical theory of the last few years of modern scientists in the reign of high school teacher training.
\end{abstract}

Key words: teacher, high school teacher, higher education, high school teacher training.

\section{Introduction.}

The problem of high school teacher training has been the subject of special scientific research in pedagogical theory for decades. In high school educators have formed some traditions for studying various aspects of the vocational training of future high school teachers, as well as trends emerged in looking at the current state of higher education. In the context of our study it will be useful to highlight the scientific advances in pedagogical theory of the last few years of modern scientists in the reign of high school teacher training.

According to the "Concept of the Gallery of the development of continuing education" and the "National Strategy for the development of education in Ukraine for 2012 - 2021 years" in the field of education. The main objectives in the field of professional education are not only the quality training of teachers for all areas of education, but also the creation of an effective system of training and upgrading the qualification of scientific and pedagogical and pedagogical staff on the basis of the integration of national superstitions of world significance and established European traditions of support for the development of educators, able in the process of constant improvement to carry out professional activities on the basis of humanism, democracy, fair competition and high technology. The problem of training of pedagogical workers is particularly relevant for the current high professional education, as it is assigned a special role: providing the Ukrainian labor market with mobile qualified professionals.

International education documents, such as the "International Standard Classification of Education" (ISCED-2011), establish a high dynamism of the modern world, the emergence of new spheres of human activity, differently directed 
demographic trends, which, together with the rapid development of technological progress, cause the need to change priorities in demands for competencies of future professions. These processes are taking place on the basis of the aspirations of our country to join the world educational space, in accordance with current trends in the world. Most of these approaches are defined in the National Strategy of Education Development in Ukraine for the period up to 2021 as the strategic directions of education development and the main objectives of this legislative document [1].

\section{The main text.}

Thus, N. Batechko reveals the peculiarities of using the acceleration approach as a theoretical and methodological basis for modeling of practical training of high school teachers in the master's program. In particular, the author considers the advantages of master's programs as a favorable environment for the formation of the personality of the future teacher, who seeks constant self-development and selfimprovement. Based on the data analysis of self-recognition, self-education, selfdevelopment and self-development of the future teacher of higher education institution the stages of his formation as a professional and personality are defined and the acmeological model of his training in the conditions of studying in the master's program is created [2]

M. Weintraub analyzes the problems of positive and negative effects of the technogenic world and ways to solve them in the professional training of high school teachers. The author points to the need to develop a methodological framework for personal and professional development and self-development of high school teachers in the context of internationalization of the educational space. Particular attention is paid to the qualities that contribute to the development of competencies of high school teachers, encourage them to more effective pedagogical work. The works of $\mathrm{M}$. Weintraub formulated the prospects of professional growth and development of high school teachers' personalities, which improve pedagogical work and prepare them for the successful implementation of the natural and civilizational crisis. The author has developed a formulation of professionally important qualities of a high school teacher as a function of 10 components, which he maintains during the professional training, development and self-development [3]

The work of N. Varg analyzes the specificity of the formation of research competence of the future high school teacher in the U.S. master's program. In particular, he suggested that the specific features of the American high school include its flexibility, differentiation, individuation, use of a wide range of innovative technologies and programs, and ability to adapt flexibly to the demands of practice. Varga argues that this greatly affects both the quality and efficiency of training high school teachers and their competitiveness in the labor market. The author investigated the forms and methods of development of investigative competence of a future high school teacher in the USA.

The author has established that the research competence of an aspiring high school teacher is an integral personality quality that reflects the integrity of theoretical and practical readiness of a teacher for scientific and research work, aimed at transforming educational practice, and requires the ability to self-motivated, responsible, initiative decision-making of research tasks in professional activities. 
Researchers identified such components of research competence as professional research competence, scientific communication competence and educational competence. In the research of N. Varg established that the formation of research competence of a future high school teacher in the United States is a continuous process and takes place in the course of his professional training through the use of certain forms and methods of teaching: lectures and seminars based on the "teaching as research" model, practice, individual, group and self-study work, consultations, and research paper writing, research work, project, research assignments, case analysis, portfolio, cognitive workshop, simulation modeling, self-assessment maps, reflexive analysis, etc. [4].

$\mathrm{N}$. Varg's series of scientific papers is devoted to the problem of professional training of high school teachers in the United States, where successful experience has been accumulated in functioning the system of training and upgrading the qualification of teaching staff. The scientist believes that this system is flexible and variable, able to quickly adapt to the needs of the modern information society and proves it, The leading institutions of higher education, which have a powerful scientific and methodological potential, play a key role in this process. The author found that the profession of high school teacher in the U.S. involves research and pedagogical activities, the first of which leads to a high scientific potential of the teacher, and the other - is acquired as a result of teaching experience.

The system of vocational training, retraining and upgrading the qualification of a high school teacher, in the opinion of N. Varga, there are three stages: Preprofessional training of teachers in the framework of a master's degree or aspirantura; activities as an assistant teacher, which is a joint line between the pre-professional and professional phases, which involves direct scientific and pedagogical practice and improvement of professional and pedagogical skills under different programs of upgrading qualification (national, institutional, individual) [5].

L. Verchenko devoted his scientific and pedagogical works to the development of diagnostic tools for assessing the levels of development of social and political competence of high school graduates. In particular, a set of methods that can be used to diagnose the indicators and criteria of social and communication competence of high school teachers was disclosed [6].

T. Golovanova analyzes the theoretical foundations of professional competence of a high school teacher. She points out that the research and practice of professional and pedagogical competence in education have grown over the past two decades. In particular, a large part of this effort is focused on developing the competencies of school teachers. The researcher reviewed various scientific approaches to a better understanding of professional competencies and professional competence of higher education institutions [7]

K. Gnezdilova and O. Tymchenko devoted their research to the problem of modernization of the content of educational and professional training of future high school teachers for their management activities, indicating the relevance at the present stage of higher education reforms. In their opinion, the command of carrying out effective management activity of the teacher is the formation in him/her system of management skills as readiness and ability to carry out management actions in any 
professional situations. In accordance with the managerial functions of the teacher they suggested a list of managerial skills, the level of formation of which they studied in the process of research and experimental work [8].

To study peculiarities of professional training of medical university teacher in the USA scientific and pedagogical works are devoted. The author points to the necessity of critical analysis of the positive experience of advanced countries, the urgency of which is strengthened by the fact that the quality of training of physicians in the United States directly depends on the training of medical university teachers. According to T. Gorpinich, professional training of medical school teachers consists of three stages: pre-professional, post-professional training and advanced training, the efficiency of which at each stage consists in a quick response of the educational system to the events and demands of the time [9].

The role, analysis of the essence, components, and peculiarities of using casetechnology in the training of modern higher education teachers are given in works by O. Druganovaova and I. Martinenko. The authors argue that the pedagogical potential of technology is extremely great. So, to the list of its advantages they include a new model of student behavior in educational activities - from passive knowledge acquisition to active, creative, research self-study activity, which increases cognitive interest, significantly influences the activity of thinking and stimulates intellectual activity, provides each participant with the possibility to develop their own trajectory of self- and mutual learning.

According to scientists, an important role in enhancing the effectiveness of shaping the professional competence of a high school teacher is the creation of a professional and creative environment, which simulates professional activity as much as possible, gives the opportunity to try to live in a real-life situation, "get used to it" and "live with it for a certain period of time"; Forms a concrete idea of the complexity of the pedagogical work, becomes an effective way to develop the professional qualities of a master. The authors believe that implementation of casetechnology is effective only in close cooperation between the teaching staff and students and only on the condition of their motivational readiness both for professional self-development and for participation in such educational activity. Of great importance here is the ability of the teacher to create a professional and pedagogical situation, to recognize the body of knowledge that is necessary for its fulfillment; his or her interpersonal skills and qualities, and ability to resolve and prevent conflicts. The level of skills formed in the masters to conduct self-directed search activity, skills of oral and written communication, ability to work together as a team, etc., also become important [10].

Some reflections on the role and place of historical and pedagogical knowledge in the system of professional training of the modern high school teacher found in the works of O. Druganova. She said that the emphasis in the content of the course "High School Pedagogy" should be given to a systematic study of the heritage of prominent teachers of the country's academics, Their activity is connected with the formation and development of higher education and school in Ukraine in different historical periods, especially in the period of the 19th century. The author paid special attention to the significance of $\mathrm{M}$. Pirogov's creative heritage, characterized the main 
provisions of the scientific elaboration of the educator that have not lost their relevance and can be creatively reinterpreted and implemented in the practice of training of modern teachers of higher education institutions [11].

Interactive technologies of forming the rhetorical culture of future high school teachers are described in the works of O. Zalyubivs'ko. For example, she analyzed the notion of "learning technology", "interactive teaching" through the prism of rhetoric teaching, and formulated discursive positions on the use of the notion of "learning technology", in particular, on signs of technocratism in the technological approach to teaching. The author suggested the use of technology at the subject level as a totality of methods, as well as in connection with the presence of a distance component using information and communication technologies. The author proposed an interactive technology for shaping the rhetorical culture of high school graduates, which combines traditional, active and interactive methods of teaching rhetoric with the priority of the latter.

For O. Zalyubivska, the orientation of the formation of students' rhetorical culture for the future scientific and pedagogical activity involves: 1) the link between rhetoric and the psychological and pedagogical disciplines; 2) the use of appropriate didactic material in the classes of rhetoric; 3 ) using pedagogically significant methods and techniques of rhetoric teaching (discussion, games, micro activities, posing problematic questions, etc.). This technology is presented on the basis of humanistic, axiological, communicative methodological approaches and principles of partnership of subjects of the pedagogical process, thinking and thinking activity and interactivity, the integration of rhetorical theory with speech practice, selfdetermination and the choice of an individual educational trajectory, creative productivity, stimulation of scientific and research activities, social and emotional comfort [12].

M. Koziar and Y. Kozlovskiy have outlined the essence and role of the leading aspects of activity of higher education teachers (educational, educational, managerial, organizational, methodological, scientific, innovative, etc.). Thus, scientists have identified the peculiarities of scientific and pedagogical aspects and the modern requirements for them in EHE conditions, including: direct participation of participants in the educational process in scientific and research activities; interconnection of scientific and educational processes in EHE; Integration of sectoral and pedagogical knowledge of modern EHE teaching and research staff; establishment of link between scientific and research activity and teaching and educational process; coordination of scientific and organizational activities, establishment of international links, Ensuring the improvement of the qualification of teachers and organization of joint research work of teachers and students, providing advice and assistance in research work, etc. Researchers have brought the necessity of gradual use of differentiated and integrative approach to the training of high school teachers and substantiated this by examples of activities of teachers in the field of civil protection and computer technology [13].

Theoretical foundations of professional and pedagogical activity of a high military school teacher are substantiated by O. Krasnitsky. She highlighted the importance of pedagogical image and authority in ensuring the success of the 
professional activity of the teacher of a higher education institution, revealed the content and structure of the pedagogical mastery of the teacher, identified the determinants of its development. The researcher revealed aspects of the formation and development of oratorical skills of a high military school teacher, revealed features of professional and pedagogical communication, prevention of conflicts in the interaction of subjects of the educational process. Her work highlights ethical aspects of pedagogical mastership of a high military school teacher, characterizes ways and means of preventing professional stress, burnout and deformations [14].

Studying high school teacher training in the recent doctoral studies, we should note that this area has some differences. In particular, the work of L. Lebedik reveals theoretical principles of training high school teachers to design didactic systems in a master's program [15].

Theoretical and methodological foundations of contextual training of high school graduates for self-organization in professional activity are presented in works by N. Mironchuk [16]. The scientific road of research of the PhD level of the last years in Ukraine is presented by works on pedagogy O. Lysenko. Lysenko, in which the peculiarities of professional training of pedagogical staff in the system of higher education in Ireland were revealed [17], I. Fedorchuk, who outlines some aspects of the modernization of the content of higher education in the countries of the Caucasus region (Azerbaijan, Armenia, Georgia) [18], A. Litvinova. Litvinov, who outlined the peculiarities of shaping the readiness of high school graduates to implement educational innovations in high school practice [19].

O. Lokshina's works are devoted to the European policy of training high-skilled scientific and pedagogical staff looking at the European principles and implementation of European standards in Ukrainian education studies. Thus, the researcher states that apart from the synchronization of legislation, the Ukrainian science is developing and implementing European approaches, forms, methods in the conditions of harmonization of the Ukrainian science with European research standards. However, the training of high qualification scientific and pedagogical staff requires modernization on a new philosophical basis.

The Jerelian basis of the research is based on official documents of Ukraine and the European Union on the development of science, research and innovations. O. Lokshina notes that it is important for understanding in Ukraine the European experience in training of postgraduates to analyze ideas on scientific leadership. She brings the importance of taking into account the "Salzburg II. Recommendations" for the training of scientific and pedagogical staff. In particular, the point is about ensuring the professional growth of scientific leaders, who must be professionalsresearchers, endowed with leadership and mentoring skills, formation of a culture of scientific mentoring through formal training or informal exchange of experience with colleagues is the institutional responsibility and priority of formation of the scientific potential of the institution of higher education / scientific institution [20].

N. Mironchuk's work analyzes the experience of training high school teachers at universities in Germany, Great Britain, USA, Canada, and Australia. The author identifies the areas of training of high school teachers in a master's program and shows the diversity of educational programs of master's training and features of their 
content. In particular, it is noted that the master's programs in foreign universities have a professionally practical orientation, develop skills of self-study, professional development and life-long learning. Also noted the value of the practical component in the professional training of teachers [21].

O. Naboka's research on training of high school graduates for designing professional and oriented teaching technologies reveals the main components of this process. The author says that considering the tendencies of renewal and modernization of the educational process, the conceptual basis for the training of future high school teachers to design professionally-oriented technology is based on the understanding of professionally-oriented teaching technology as a system of forms, methods, techniques and tools aimed at achieving the goals of the professional training and bring it as close as possible to the conditions of the professional activity, ensuring the formation of a competitive specialist in the labor market.

According to O. Naboka, the development of professionally-oriented teaching technologies must be carried out in accordance with the principles of systemic integrity, diagnostic, differentiated purposefulness, stimulation and motivation of students' positive attitude to learning, flexible algorithm and variability of learning, professional competence and synergistic information support of learning. The systemfulness in the process of projecting is ensured by the totality of such components of professionally-oriented teaching technology as purposeful, content, process-activity, diagnostic and regulating.

The author argues that the main conditions for the use of vocationally-oriented learning technologies is the creation of a suitable educational environment of the institution of higher education, where the implementation of the mentioned didactic system and provision of positive psycho-motional environment in the process of practical training as a systematic realization of the subject-subject interaction of students and teachers with active stimulation of students to self-development takes place, self-improvement, self-development, individualized choice of the type of professionally-oriented teaching technology, and the use of innovative teaching tools for professional training of higher education institutions [22].

\section{Conclusions.}

Thus, the problem of preparation of a high school teacher in the master's program was a subject of research of modern Ukrainian and foreign scientists, this problem was the subject of dissertation research of the last years in Ukraine. In particular, such scientific and pedagogical aspects of the mentioned problem as the basis of professional training of high school teachers, professional training of high school teachers in the context of internationalization of the educational space were studied, socio-cultural determinants of modernization of the content of training of future high school teachers for self-organization in professional activity, peculiarities of the activity of higher education teacher in the conditions of staffing of secondary education, modern approaches to selection of training methods for higher school graduates in the conditions of master's degree.

The role and place of historical and pedagogical knowledge in the system of professional and pedagogical training of today's high school teachers, Case technology as an effective method of training modern high school teacher, 
pedagogical mastery of high school teacher, pedagogical conditions for the formation of readiness of graduates to provider of educational innovations in the practice of high school, the peculiarities of internship as an important stage in the preparation of the medical high school teacher, problem of self-education of high school graduates, training of high school graduates for professional interaction, structure and content of managerial skills of high school graduates, organization of practical training of master's students for pedagogical activity, etc.

\section{References:}

1. Decree of the President of Ukraine on the National Strategy for the Development of Education in Ukraine for the period up to 2021, https://zakon.rada.gov.ua/laws/show/344/2013

2. Batechko, N. (2018), Acmeological model of teacher training in high school. Continuing professional education: theory and practice. 1-2. 60-68.

3. Weintraub, M.A. (2019), Professional training of a high school teacher in the context of internationalization of educational space. Scientific Bulletin of the Flight Academy. Series: Pedagogical sciences. 6. 36-41.

4. Varga, N.I. (2020), Forms and methods of formation of research competence of the future teacher of higher education of the USA in a magistracy. Science. spring Uzhhorod University. Series: "Pedagogy. Social work". 2 (47). 33-37.

5. Varga, N.I. (2019), Organizational principles of professional training of a teacher of higher education in the United States. Scientific Bulletin of Uzhhorod University. Series: Pedagogy. Social work. 2. 26-30.

6. Verchenko, L.S. (2018), Diagnosis of levels of development of social and communicative competence of future teachers of higher education. Bulletin of Alfred Nobel University. Series: Pedagogy and psychology. 2. 160-169.

7. Golovanova, T.P. (2018), Theoretical principles of professional competence of the future teacher of higher education. Bulletin of Zaporizhia National University. Pedagogical sciences. 1. 68-75.

8. Gnezdilova, K.M., Timchenko, O.S. (2020), The structure and content of management skills of future high school teachers. Scientific Bulletin of the Flight Academy. Series: Pedagogical sciences. 7. 26-31.

9. Horpinich, T. (2019), Training teachers for professional activities in medical universities in the United States. Pedagogical sciences: theory, history, innovative technologies. 3. 143-154. http://nbuv.gov.ua/UJRN/pednauk_2019_3_15.

10. Druganova, O.M., Martynenko, I.I. (2019), Case technology as an effective way to train a modern high school teacher. Theory and methods of teaching and education. 46. 48-58. http://nbuv.gov.ua/UJRN/znpkhnpu ttmniv 2019466.

11. Druganova, O.M. (2019), The role and place of historical and pedagogical knowledge in the system of professional and pedagogical training of a modern high school teacher. Scientific notes of the department of pedagogy. 44. 87-102. http://nbuv.gov.ua/UJRN/Nzkp 20194411.

12. Zalyubivska, O.B. (2018), Interactive technology of formation of rhetorical culture of future teachers of higher school. Bulletin of Vinnytsia Polytechnic Institute. 5. 105-113. http://nbuv.gov.ua/UJRN/vvpi_2018_5_16. 
13. Kozyar, MM, Kozlovsky, YM (2019), Scientific and pedagogical aspects in the professional training of a high school teacher. Pedagogical almanac. 41. 89-95. http://nbuv.gov.ua/UJRN/pedalm $201941 \quad 15$.

14. Krasnytska, OV (2020), Pedagogical skills of a teacher of higher military school: a textbook. Kyiv: Condor. 528 p.

15. Lebedik, L.V. (2019), Theoretical bases of preparation of teachers of higher school for designing of didactic systems in the conditions of a magistracy: author's ref. dis. ... Dr. Ped. Science: 13.00.04 / Gos. University "Donbass. state ped. un-t ». Slavyansk, 40 p. : fig., table.

16. Mironchuk, N.M. (2020), Theoretical and methodical bases of contextual preparation of future teachers of higher school to self-organization in professional activity: author's ref. dis. ... Dr. Ped. Science: 13.00.04 / Zhytomyr. state Univ. Ivan Franko. Zhytomyr, 2020. 40 p.

17. Lisenko, O.A. (2019), Professional training of teachers in the higher education system of Ireland: author's ref. dis. ... cand. ped. Science: special. 13.00.01 "General pedagogy and history of pedagogy" / [science. head Maksymenko Anatoliy Petrovich]; Kiev. nat. linguist. un-t. Kyiv, 22 p.

18. Fedorchuk, I.V. (2019), Modernization of the content of higher pedagogical education in the countries of the Caucasus region (Azerbaijan, Armenia, Georgia): author's ref. dis. ... cand. ped. Science: special. special 13.00.01 "General pedagogy and history of pedagogy" / [science. head Tezikova Svetlana Vladimirovna]; Nizhyn. state Univ. Nikolai Gogol. - Nizhyn, 20.

19. Litvinov, A.S. (2018), Formation of readiness of future teachers of higher educational institutions for introduction of educational innovations in practice of higher school: author's ref. dis. ... cand. ped. Sciences: 13.00.04 / Deaf. nat. ped. Univ. O. Dovzhenko. Deaf, 2018. 20.

20. Lokshina, O.I. (2019), On the question of the European policy of training scientific and pedagogical staff of the highest qualification: a vision of the Salzburg principles. Implementation of European standards in Ukrainian educational research: coll. materials III International. Science. conf. Ukr. assoc. Education Researchers, June 21. 2019 / Ukr. assoc. researchers of education, NAPS of Ukraine. Kyiv, pp. $112-115$.

https://drive.google.com/file/d/1FCzJc-

\section{CAMI1Lc7PYLZKH3j5RqimnQuew/view.}

21. Myronchuk, N. (2019), Master's programs of professional training of higher school teachers in foreign universities. American Journal of Fundamental, Applied \& Experimental Research. Vol. 13 (2). P. 27-31. https://ajfaer.org/index.php/ajfaer/article/view/30.

22. Naboka, O.G. (2018), Preparation of future high school teachers for the design of professionally-oriented learning technologies.

\section{Литература:}

1. Указ Президента України Про Національну стратегію розвитку освіти в Україні на період до 2021 року, https://zakon.rada.gov.ua/laws/show/344/2013

2. Батечко, Н. (2018), Акмеологічна модель підготовки викладача вищої школи в умовах магістратури. Неперервна професійна освіта: теорія і практика. 1-2. 60-68.

3. Вайнтрауб, М.А. (2019), Професійна підготовка викладача вищої школи в контексті 
інтернаціоналізації освітнього простору. Науковий вісник Льотної академії. Серія Педагогічні науки. 6. 36-41.

4. Варга, Н.I. (2020), Форми і методи формування дослідницької компетентності майбутнього викладача вищої школи США в магістратурі. Наук. вісн. Ужгородського ун-ту. Серія: «Педагогіка. Сочіальна робота». 2 (47). 33-37.

5. Варга, Н.I. (2019), Організаційні засади професійної підготовки викладача вищої школи США. Науковий вісник Ужгородського університету. Серія : Педагогіка. Соиіальна робота. 2. 26-30.

6. Верченко, Л.С. (2018), Діагностика рівнів розвитку соціально-комунікативної компетентності майбутніх викладачів вищої школи. Вісник Університету імені Альфреда Нобеля. Серія : Педагогіка і психологія. 2. 160-169.

7. Голованова, Т.П. (2018), Теоретичні засади професійної компетентності майбутнього викладача вищої школи. Вісник Запорізького національного університету. Педагогічні науки. 1. 68-75.

8. Гнезділова, К.М., Тимченко, О.С. (2020), Структура та зміст управлінських навичок майбутніх викладачів вищої школи. Науковий вісник Льотної академії. Серія : Педагогічні науки. 7. 26-31.

9. Горпініч, Т. (2019), Підготовка викладачів до професійної діяльності в медичних університетах США. Педагогічні науки: теорія, історія, інноваџійні технології. 3. 143-154. http://nbuv.gov.ua/UJRN/pednauk 2019315.

10. Друганова, О.М., Мартиненко, I.I. (2019), Кейс-технологія як ефективний спосіб підготовки сучасного викладача вищої школи. Теорія та методика навчання та виховання. 46. 48-58. http://nbuv.gov.ua/UJRN/znpkhnpu ttmniv 2019466.

11. Друганова, О.М. (2019), Роль і місце історико-педагогічних знань у системі професійно-педагогічної підготовки сучасного викладача вищої школи. Наукові записки кафедри педагогіки. 44. 87-102. http://nbuv.gov.ua/UJRN/Nzkp_2019_44_11.

12. Залюбівська, О.Б. (2018), Інтерактивна технологія формування риторичної культури майбутніх викладачів вищої школи. Вісник Вінницького політехнічного інституту. 5. 105113. http://nbuv.gov.ua/UJRN/vvpi 2018516.

13. Козяр, М.М., Козловський, Ю.М. (2019), Науково-педагогічні аспекти в професійній підготовці викладача вищої школи. Педагогічний альманах. 41. 89-95. http://nbuv.gov.ua/UJRN/pedalm $201941 \quad 15$.

14.Красницька, О.В. (2020), Педагогічна майстерність викладача вищої військової школи : підручник. Київ : Кондор. 528 с.

15. Лебедик, Л.В. (2019), Теоретичні засади підготовки викладачів вищої школи до проектування дидактичних систем в умовах магістратури : автореф. дис. ... д-ра пед. наук : 13.00.04 / Держ. ВНЗ «Донбас. держ. пед. ун-т». Слов'янськ, 40 с. : рис., табл.

16.Мирончук, Н.М. (2020), Теоретичні і методичні основи контекстної підготовки майбутніх викладачів вищої школи до самоорганізації у професійній діяльності : автореф. дис. ... д-ра пед. наук : 13.00 .04 / Житомир. держ. ун-т ім. Івана Франка. Житомир, 2020. 40 с.

17. Лисенко, О.А. (2019), Професійна підготовка педагогічних кадрів у системі вищої освіти Ірландії : автореф. дис. ... канд. пед. наук : спец. 13.00.01 «Загальна педагогіка та історія педагогіки» / [наук. керівник Максименко Анатолій Петрович] ; Київ. нац. лінгвіст. ун-т. Київ, 22 с.

18. Федорчук, І.В. (2019), Модернізація змісту вищої педагогічної освіти в країнах кавказького регіону (Азербайджан, Вірменія, Грузія) : автореф. дис. ... канд. пед. наук : спец. спец. 13.00.01 «Загальна педагогіка та історія педагогіки» / [наук. керівник Тезікова Світлана Володимирівна ] ; Ніжин. держ. ун-т ім. Миколи Гоголя. - Ніжин, 20.

19. Литвинов, А.С. (2018), Формування готовності майбутніх викладачів вищих навчальних закладів до впровадження освітніх інновацій у практику вищої школи : автореф. дис. ... канд. пед. наук : 13.00.04 / Глухів. нац. пед. ун-т ім. О. Довженка. Глухів, 2018. 20.

20. Локшина, O.I. (2019), До питання про європейську політику підготовки науково- 
педагогічних кадрів вищої кваліфікації: бачення зальцбурзьких принципів. Імплементація європейських стандартів в украӥнські освітні дослідження : зб. матеріалів III Міжнар. наук. конф. Укр. асоц. дослідників освіти, 21 черв. 2019 р. / Укр. асоц. дослідників освіти, НАПН України. Київ, С. 112-115. https://drive.google.com/file/d/1FCzJcCAMI1Lc7PYLZKH3j5RqimnQuew/view.

21. Мирончук, Н. (2019), Магістерські програми професійної підготовки викладачів вищої школи у зарубіжних університетах. American Journal of Fundamental, Applied \& Experimental Research. Vol. 13(2). P. 27-31. https://ajfaer.org/index.php/ajfaer/article/view/30.

22. Набока, О.Г. (2018), Підготовка майбутніх викладачів вищої школи до проектування професійно-орієнтованих технологій навчання. ScienceRise. Pedagogical Education.5, 23-27. http://nbuv.gov.ua/UJRN/texcped_2018 57 .

Анотація. В статье представлены результаты научно-теоретических исследований автора в области подготовки преподавателей университетов в контексте современной педагогической теории. Автор указывает, что проблема подготовки педагогов для вузов на протяжении десятилетий является предметом специальных научных исследований педагогической теории. В педагогическом образовании сложились некоторые традиции изучения различных аспектов профессиональной подготовки будущих педагогов для высшей школы, а также тенденции, выявленные при анализе текущего состояния высшего образования. В контексте нашего исследования будет полезно осветить научные наработки в педагогической теории последних лет.

Ключові слова: педагог, преподаватель высшей школь, высшее образование, университетская подготовка педагогов.

Article sent / Статья отправлена:: 02.05.2021 (C) Cherepiekhina O./ (C) Черепехина O.A. 